\title{
Youth-Led Participatory Video as a Strategy to Enhance Inuit Youth Adaptive Capacities for Dealing with Climate Change
}

\author{
Joanna Petrasek MacDonald, ${ }^{1,2}$ James Ford, ${ }^{1}$ Ashlee Cunsolo Willox, ${ }^{3}$ Claudia Mitchell, ${ }^{4}$ Konek Productions, ${ }^{5}$ \\ My Word Storytelling and Digital Media Lab ${ }^{6}$ and Rigolet Inuit Community Government ${ }^{6}$
}

(Received 25 September 2014; accepted in revised form 29 April 2015)

\begin{abstract}
Rapid climatic and environmental changes experienced throughout the Canadian North are having significant impacts on the lives of Inuit, with implications for the future of the large Inuit youth population. Within the adaptation research and practitioner community, youth voices, perspectives, and involvement are essential in ensuring representative and sustainable adaptation strategies. This paper examines the potential of youth-led participatory video (PV) as a strategy to foster known protective factors that underpin the resilience of youth and their capacity to adapt to various stresses, including impacts of climate change. The work draws on a case study from the Inuit community of Rigolet, Nunatsiavut, Labrador, Canada, where a two-week PV workshop was conducted with seven youth and followed by in-depth interviews with participants and community members. The findings show that PV may be a pathway to greater adaptive capacities because the process connects to known protective factors that enhance resilience of circumpolar indigenous youth. PV also shows promise as a strategy to engage youth in sharing insights and knowledge, connect generations, and involve young Inuit in planning and decision making in general.
\end{abstract}

Key words: participatory video; protective factors; resilience; adaptive capacity; climate change adaptation; youth; Inuit; Nunatsiavut; Arctic; Canada

RÉSUMÉ. Les changements climatiques et environnementaux rapides qui surviennent dans le Nord canadien ont des répercussions importantes sur la vie des Inuits, avec des conséquences pour l'avenir de la grande population de jeunes Inuits. Au sein de la communauté de praticiens et de recherche sur l'adaptation, la voix des jeunes, leurs perspectives et leur participation sont essentielles pour assurer la mise en œuvre de stratégies d'adaptation représentatives et durables. Cet article examine la possibilité de faire des vidéos participatives dirigées par les jeunes comme stratégie pour favoriser les facteurs de protection connus qui sous-tendent la résilience chez les jeunes et leur capacité d'adaptation face à divers agents stressants, notamment les conséquences du changement climatique. Le document s'inspire d'une étude de cas de la communauté des Inuits de Rigolet, Nunatsiavut, au Labrador, Canada, où un atelier sur la vidéo participative d'une durée de deux semaines a eu lieu avec sept jeunes, suivi d'entrevues approfondies avec des participants et des membres de la communauté. Les résultats démontrent que la vidéo participative pourrait être une façon d'améliorer les capacités d'adaptation parce que le processus est relié à des facteurs de protection connus qui améliorent la résilience des jeunes indigènes de la région circumpolaire. La vidéo participative s'avère également une stratégie prometteuse pour amener les jeunes à échanger leurs idées et connaissances, établir un lien entre les générations et faire participer les jeunes Inuits à la planification et à la prise de décisions en général.

Mots clés : vidéo participative; facteurs de protection; résilience; capacité d'adaptation; adaptation au changement climatique; jeunes; Inuit; Nunatsiavut; Arctique; Canada

Traduit pour la revue Arctic par Nicole Giguère.

\section{INTRODUCTION}

Climate change adaptation research has evolved substantially over the past decade in the Canadian North, which has experienced significant change in climatic and environmental conditions (Ford and Furgal, 2009; Ford et al., 2010; Ford and Pearce, 2012; IPCC, 2014). An increase in surface air temperatures, warming permafrost, and reduced sea ice quality, stability, and extent have been widely documented, with implications for the livelihoods

\footnotetext{
${ }^{1}$ Department of Geography, McGill University, 805 Sherbrooke Street West, Montreal, Quebec H3A 0B9, Canada

${ }^{2}$ Corresponding author: joanna.petrasekmacdonald@mail.mcgill.ca

${ }^{3}$ Cape Breton University, Departments of Nursing \& Indigenous Studies, PO Box 5300, 1250 Grand Lake Road, Sydney, Nova Scotia B1P 6L2, Canada

${ }^{4}$ Department of Integrated Studies in Education, McGill University, 3700 McTavish Street, Montreal, Quebec H3A 1Y2, Canada

${ }^{5}$ PO Box 107, Arviat, Nunavut X0C 0E0, Canada

${ }^{6}$ Rigolet Town Council Building, Rigolet, Newfoundland and Labrador A0P 1P0, Canada

(C) The Arctic Institute of North America
} 
and well-being of Inuit who maintain an intimate connection with and reliance on the natural environment for subsistence and cultural activities (Krupnik and Jolly, 2002; Ford et al., 2006, 2008; Nickels et al., 2006; Ford, 2008, 2009; Prowse et al., 2009; Cunsolo Willox et al., 2012b, 2013a; Harper et al., 2012). Inuit are experiencing this environmental change in the context of rapid and extensive social, cultural, political, and economic changes that stem from the history of colonization (Lehti et al., 2009; Richmond, 2009; Ford et al., 2010; Cameron, 2012). Despite being faced with a challenging context, however, Inuit communities have been demonstrating significant resilience, both by adapting their lifestyles and traditions to respond to multiple and interconnected pressures and changes and by proactively working towards supporting and maintaining healthy communities and cultures (Krupnik and Jolly, 2002; Ford et al., 2006; Nickels et al., 2006; Wenzel, 2009).

Resilience involves dynamic processes of adaptation, growth, and development that can lead to positive outcomes in responding to challenges and stresses, both past and present (Kirmayer et al., 2011; Allen et al., 2014). In the current Arctic Indigenous context, resilience means having the knowledge, skills, and resources to cope with and adapt to immense, significant changes in the physical environment and, perhaps more significantly, to navigate rapid changes in cultural, political, and socio-economic conditions successfully at the same time.

Considering the dynamic social, cultural, political, and economic landscape in the North, the involvement of Inuit communities in research is critical to understanding the potential future vulnerabilities and planning for adaptation (Ford and Pearce, 2012; Harper et al., 2012; Pearce et al., 2012; Cunsolo Willox et al., 2012b, 2013a; Ford et al., 2014). Involving community partners in the research process can also bring awareness and respect of the culture and context of the partner community, facilitate capacity development, and highlight local knowledge, voices, and experience that advance research in a way Western science cannot do alone (Bird et al., 2009; Castleden et al., 2012; Cunsolo Willox et al., 2012a; Smith, 2012). In this context, research on human dimensions of climate change in the Canadian North has seen increasingly meaningful partnerships with and leadership by Inuit communities. Such research uses diverse approaches premised on active community participation through all stages of the research process (Harper et al., 2012; Pearce et al., 2012; McClymont Peace and Myers, 2012). These approaches include PhotoVoice (Healey et al., 2011) and digital storytelling (Cunsolo Willox et al., 2012b).

Despite the increase of Inuit participation, youth voices and involvement remain largely absent in climate change research and adaptation planning - an absence which has been identified as an important research gap (Ford and Pearce, 2010; Petrasek MacDonald et al., 2013a). Since Inuit youth are an important and growing population and are already having to adapt and cope with environmental and climatic changes among other challenges facing their future (Petrasek MacDonald et al., 2013a), adaptation research, policy, and practice can become more representative, effective, and sustainable by mobilizing a younger generation that is invested in and can advocate for these changes. Indeed, the younger generation offers its own perspectives, experiences, and skills. If given a chance to participate in adaptation research through meaningful and innovative methods, youth has the potential to make important contributions as a crucial stakeholder.

While adaptation research, policy, and practice can no doubt benefit from engaging and mobilizing youth, the potential benefits of this involvement for the young people themselves are perhaps more important. The opportunity to be meaningfully involved in their community, whether through research projects or community programs, is one of the many protective factors known to enhance circumpolar Indigenous youth resilience to a variety of stresses, including climate change challenges (Mohatt et al., 2004; Allen et al., 2006; Ford et al., 2012; DeCou et al., 2013; Petrasek MacDonald et al., 2013b). Other protective factors that promote Indigenous youth resilience and have been identified by community-based research across the North include positive role models, community connectedness, continuous communication and interaction, connecting generations, belief in self, sense of purpose, staying busy, community pride, and cultural traditions and practices (Mohatt et al., 2004; Allen et al., 2006; Wexler and Goodwin, 2006; Bals et al., 2010; Wexler, 2014; Wexler et al., 2014). These known protective factors are synonymous with key characteristics of strong adaptive capacity. For example, connecting youth with older community members is not only a factor well established as important for circumpolar Indigenous youth resilience (Kirmayer et al., 1998; Wexler and Goodwin, 2006; Kral et al., 2011; DeCou et al., 2013; Wexler et al., 2013, 2014), but also an essential aspect of sharing traditional knowledge between generations, which, in turn, can increase adaptive capacity to respond to climate change impacts and climate-related challenges (Ford et al., 2006, 2010; Pearce et al., 2011). Thus, protective factors play an important role in building youth resilience and adaptive capacities within circumpolar Indigenous populations.

Digital methods, such as PhotoVoice, digital storytelling, and participatory video, are examples of participantcentered, youth-focused research methods that have been used successfully across a wide range of academic disciplines and multiple geographic regions and may be one avenue through which to promote and support protective factors (Stewart et al., 2008; Foster-Fishman et al., 2010; Iseke and Moore, 2011; Cunsolo Willox et al., 2012b; de Lange and Geldenhuys, 2012; Hung et al., 2012; Jardine and James, 2012; Ohashi et al., 2012; Alrutz, 2013; Chonody et al., 2013; Genuis, 2013). In northern Canada, digital media, particularly films, have long been used in research and to share Inuit life and culture with broad audiences; examples are films such as The People's Land (Brody, 1976), Qapirangajuq: Inuit Knowledge and Climate Change (Kunuk and Mauro, 2010), and People of a Feather (Heath, 2012). 
Youth-led filmmaking is also well-established in the North, with groups such as the Arviat Film Society, Conversations with the Earth, and Konek Productions leading the way for digital communications. Building on this history, and recognizing the need to encourage and increase youth participation in climate change scholarship, this paper examines whether youth-led participatory videomaking within the context of climate change adaptation research has the potential to support known protective factors and thus enhance adaptive capacities and contribute to building youth resilience.

\section{METHODS}

\section{Partner Community}

This project took place in Rigolet, Nunatsiavut, Canada $\left(54^{\circ} \mathrm{N}, 58^{\circ} \mathrm{W}\right.$, Fig. 1). Nunatsiavut is one of four Inuit regions of the Inuit Nunangat (Inuit Homelands). Formalized through the Labrador Inuit Land Claims Agreement in 2005, it encompasses a wide range of landscapes, including subarctic tundra, coastal barrens, and boreal forest. This region supports and sustains people who live in five coastal communities, and Rigolet is its southernmost community.

Rigolet is a small, remote, coastal settlement on the northeast coast of Labrador, with 306 community members, $85 \%$ of whom identify as Inuit (Statistics Canada, 2011a, b). Like the overall Canadian Inuit population, the Rigolet community is young and growing; children and youth (ages $0-25$ ) represent $31 \%$ of the population, and more than half of these are youth (ages 12-25) (Statistics Canada, 2011b). Northern Lights Academy, the local school from kindergarten to Grade 12, has a total of 50 students. Inuit in Rigolet continue to rely on the land, which is a vital part of their lives and culture (Cunsolo Willox et al., 2012a, b, 2013a; Harper et al., 2012). Traditional cultural activities valued and practiced throughout the year include fishing, hunting, trapping, berrypicking, and trips to a family cabin. Land activities such as hunting also contribute to the mixed economy of the region, in which people participate both in subsistence harvesting and in wage employment, such as public administration or resource extraction. Along with other needs for transportation in and around the community, cultural activities on the land and subsistence harvesting rely in winter on ice and snow conditions adequate for snowmobiles. As there are no roads in or out of Rigolet, the community is accessible only by plane or in summer, by boat, both of which depend on good weather conditions. Environmental and climatic changes and variability have been and will continue to be experienced by the community of Rigolet and link to a wide range of impacts on lives and livelihoods of community members (Table 1) (Cunsolo Willox et al., 2012a, 2013b). Rigolet also houses the My Word Storytelling and Digital Media Lab, which was established in 2009 as a community-run participatory multi-media lab with computer and media equipment, resources, and

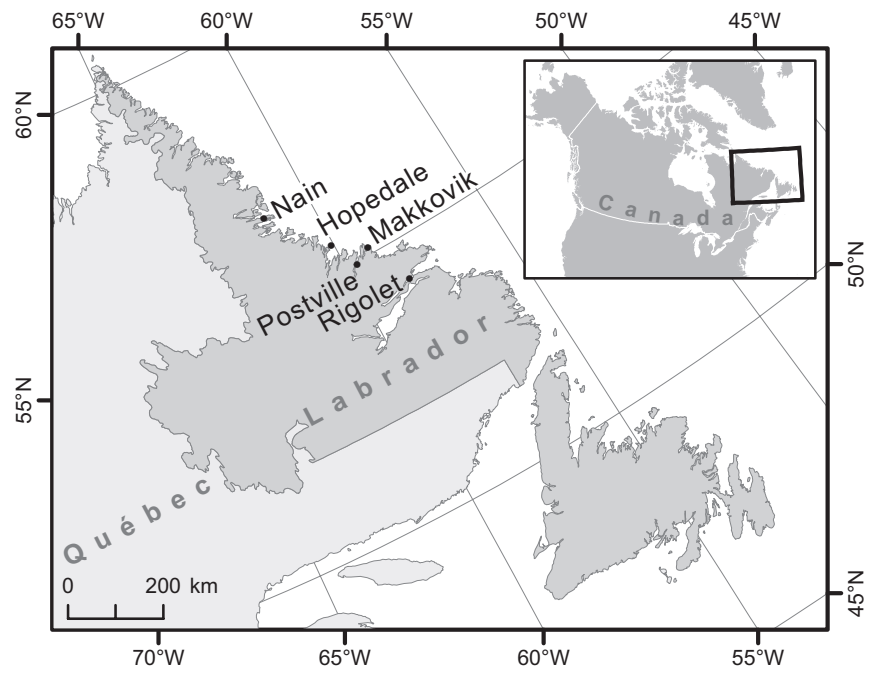

FIG. 1. The community of Rigolet is the southernmost community in Nunatsiavut, Labrador, Canada $\left(54^{\circ} \mathrm{N}, 58^{\circ} \mathrm{W}\right)$.

support available to the community. The My Word Lab has worked with Inuit youth and adults throughout Nunatsiavut to create digital stories on various themes, including climate change, and has on-going media projects using a variety of research and digital media strategies.

Our community-led project partnered with the My Word Lab and with Konek Productions, an Inuit youth-led film company based in Nunavut, to provide training in filming and editing and help facilitate a participatory video workshop. Thus this project united local digital media experts and Inuit youth filmmakers to create a facilitation team with technological skills and experience working in partnership with researchers and youth.

\section{Participatory Video}

Participatory video (PV) is a digital media research method with roots in community activism and social development that aims to shift power dynamics by having participants direct and control the creation of a film on a topic of research and community interest (Kindon, 2003; Lunch, 2007; Blazek and Hraňová, 2012; Milne et al., 2012). The method prioritizes community perspectives, place-based knowledge, and local narratives in research (Lunch, 2007). Focus is on the process of filmmaking and on discussions, relationships, and opportunities for knowledge sharing and learning that arise from this process (Lunch, 2007; Blazek and Hraňová, 2012). In addition, PV has proven to be an effective strategy for sharing knowledge and information with diverse audiences including policy makers and other communities (Ferreira, 2006; Lunch, 2007).

Participatory video has been applied by a variety of users including youth, women, and Indigenous communities, and used in a diverse array of contexts. For example, Blazek and Hraňová (2012) used PV in Bratislava, Slovakia, to explore youth perspectives on neighbourhood violence; Moletsane et al. (2009) worked with women in rural South Africa on 
TABLE 1. List of the current and projected climatic and environmental changes documented in Nunatsiavut and the impacts and risk factors for the community of Rigolet (Cunsolo Willox et al., 2012a, 2013b). The impacts and risk factors in column 2 are not associated with particular climatic and environmental changes.

\begin{tabular}{ll}
\hline \hline Climatic and environmental changes in Nunatsiavut & Impacts and risk factors in Rigolet \\
\hline - Increased seasonal temperatures & - Increased risk in foodborne and waterborne diseases \\
- Increased frequency and intensity of storms and rainfall & - Increased susceptibility to mental and emotional health challenges \\
- Decreased snow quality and amounts & - Disruptions to the ability to practice harvesting and land-based activities \\
- Changes in snowfall patterns & (e.g., hunting, fishing) that hold cultural and social importance, that are relied \\
- Decreased ice stability, thickness, and extent & upon for subsistence, and that are important transfer for intergenerational \\
- Later ice freeze-up in the fall and earlier ice break-up & knowledge \\
in the spring & - Safety concerns for traveling on the snow and ice, especially in spring and fall \\
- Rising water levels and retreating coastlines & - Challenges to food security from dependence on plane or boat to transport market \\
- Changes in wildlife behaviour and migration & foods \\
- Changes in vegetation growth patterns & - Impacts on community connectedness and overall community mood and well-being \\
\hline \hline
\end{tabular}

community issues such as poverty, gendered-based violence, and the AIDS pandemic; and Mistry and Berardi (2012) investigated connections between social memory and natural resource management using PV in Guyana. In the context of climate change adaptation, there are examples of PV projects in Malawi, the Bahamas, Argentina, and Indonesia that have been organized and supported by non-governmental organizations (Suarez et al., 2008). Furthermore, initiatives such as Conversation with the Earth (http://conversationsearth.org) focus on Indigenous voices within the context of environmental and cultural change around the world, from Canada to Peru to Kenya. As Suarez et al. (2008) argue, however, researchers have yet to seriously engage PV in climate change adaptation research.

Using PV in research offers a wealth of potential benefits and advantages, but as with other participatory visual methods, challenges and ethical considerations also arise from the nature of media, representations of participants and voice, and the power dynamics within the process. Indeed, when visual methods are used, certain truths, knowledge, and subjectivities of participants are shaped in part by the medium (Piper and Frankham, 2007; Allan, 2012). Furthermore, previous experiences and perceptions of the medium (e.g., video), along with other exterior factors (e.g., relationships with others, personal circumstances, societal contexts), inevitably direct the way participants choose to engage with the process and the way in which they represent themselves and their lives (de Block and Buckingham, 2008; White and Bushin, 2011; Allan, 2012; Mistry and Berardi, 2012). There can also be a great risk of highlighting and privileging only selected voices within a community or even within the participant group (Mayer, 2000). Thus, PV should not be used to search for an authentic voice or a singular truth, but rather to highlight and respect the diversity of representations and interpretations (Kindon, 2003; Piper and Frankham, 2007; Guillemin and Drew, 2010; Luttrell, 2010; cf. Jackson and Mazzei, 2009).

$\mathrm{PV}$ requires constant and critical reflexivity to consider the experiences and outcomes for all actors involved (Pain, 2008). If all actors are to benefit from being involved in the research, there must be constant negotiation throughout the process between different interests, personalities, and relationships, which constantly transform, rearticulate, and renegotiate their positions as the experience unfolds and relationships evolve (Blazek and Hraňová, 2012). While one of the core aims of PV is to destabilize traditional researcher/participant duality and hierarchical power relations by having participants speak for themselves (Kindon, 2003; Pain, 2004; Parr, 2007), it is naïve to expect all participants to feel ownership and control (Blazek and Hraňová, 2012) and it is important to also consider power relations between the youth participants themselves (Schäfer and Yarwood, 2009). Within the participant group, power hierarchies will naturally emerge based on local context, relationships, and personalities affecting differences in feelings of ownership and participation, and this should be expected and incorporated into the process (Schäfer and Yarwood, 2009; White and Bushin, 2011; Blazek and Hraňová, 2012; Mistry and Berardi, 2012).

\section{Data Collection}

The fieldwork was carried out over three phases: a scoping trip, a participatory video workshop, and in-depth follow-up interviews (Table 2).

During the scoping trip in March 2013, the project idea was presented to students in Grades 7-12 (ages 12-17), who were invited to participate. Seven youths (two males and five females, aged 12 to 16) joined the project. All participants were familiar with video technology, and many were already skilled in the use of the camera equipment and editing software presented in the workshop; however, all received individual media training so they could enhance and expand their skills. Participant familiarity with video technology meant that the potential challenges from learning how to use digital media equipment when doing PV were not experienced in this particular case (de Block and Buckingham, 2008).

The participatory video workshop took place in spring 2013 and was structured over the course of two weeks for two hours every weekday. During the first week, participants decided on a film topic, planned its content, were trained in camera equipment, and began filming. During the second week, the youth learned about and used iMovie and Final Cut Pro X editing software to edit short clips from the footage they had recorded. Using these clips and 
TABLE 2. Summary of the phases of fieldwork.

\begin{tabular}{|c|c|c|}
\hline Phase & Activity & Time frame \\
\hline Phase 1: Scoping Trip & Meeting with town council, principal, and students to discuss project & 5 days, one month prior to Phase 2 \\
\hline \multirow[t]{4}{*}{ Phase 2: Participatory Video Workshop } & Planning and training & Week 1, Day 1 \\
\hline & Filming & Week 1, Days 2, $3 \& 4$ \\
\hline & Editing & Week 2 \\
\hline & Community Screening & Weekend evening after Week 2 \\
\hline Phase 3: Follow-up in-depth interviews & Interviews with youth participants, parents, teachers, community members & Week 3 \\
\hline
\end{tabular}

incorporating other footage, the facilitators from Konek Productions edited the film with direction from the youth. At the end of the workshop, a well-attended community screening took place where the youth could share their film and celebrate the end of the project.

The resulting production, Life in Rigolet, is a 17-minute video (https://www.youtube.com/watch? $\mathrm{v}=$ efzp2gvZQvc) that tells the story of what it is like to be a youth in the community of Rigolet in the winter. While the researchers' interest in approaching this project was to focus on youth priorities and perspectives of community climate change adaptation, the focus and content of the film were left up to participants according to the principles of PV. At the beginning of the workshop, participants decided that they wanted to showcase their community, tell a story about their lives, and create a film about the activities that fill their time in the winter. They chose to film various winter activities such as sliding (i.e., tobogganing down a hill), going on a boilup (i.e., a traditional cultural practice of going out on the land for a campfire), being on a snowmobile, spending time at the youth center, and playing games in the school gym. Therefore, the film did not include information about climate change adaptation as such. From their strong familiarity with PV literature, the research team was aware that the expectations and aims of researchers and participants might diverge; yet, since this research was community-led and many of the researchers and facilitators were Inuit, we worked proactively to mitigate this tension. We approached and facilitated the project with active attention to continually adjusting imbalances in control or expectations, as well as ensuring flexibility to meet the youth participants where they were, reflecting their lived experiences. Indeed, as Garrett (2010) notes, researchers who are dedicated to facilitating a process that is representative of participants will accept that the research question might completely change. Indeed, the contextual aspect and complexity of the PV process challenge researchers to remain flexible and comfortable with changes in their research question but also provide the opportunity for research to uncover hidden spaces accessed only through true participatory research (Garrett, 2010). Acknowledging this, it was hoped that participants would take ownership of the process and shape the outcome according to their own interests, ideas, skills, and values and would contribute rich, unanticipated, and meaningful understandings of our research questions.

After the workshop, one week was spent conducting indepth, semi-structured and open-ended interviews $(\mathrm{n}=21)$ to examine whether and how participatory video can support known protective factors that have been identified to underpin youth resilience to a variety of stresses, including the impacts of climate change. Interviews were conducted with youth participants $(n=7)$, parents $(n=4)$, teachers $(n=4)$, youth center staff $(n=1)$, community members $(n=$ $2)$, a council member $(n=1)$, and the project team $(n=4)$. The interviews were conducted in a conversational manner to engage participants in dialogue and allow interviewees to direct conversation, and with space for the interviewer to pursue interesting comments (Kvale, 1996). All interviews were conducted in person, in English (the participants' language of choice), at a location chosen by the participant, and interviews were audio recorded with permission of the participants.

The interview with youth participants consisted of 37 open-ended questions grouped in three sections: film content, film process, and film evaluation. The questions were used primarily as a guide to initiate discussion, giving the interviewer the flexibility to keep the interviews conversational, to go off-script, and to choose questions in the order best suited to the direction of the conversation. A fourth section on protective factors had 32 statements to be answered using a Likert scale with categories of "strongly agree," "agree," "disagree," and "strongly disagree," as well as "I don't know" or "Refuse" (Table 3). The protective factor section of the interview was based on a systematic review of the literature on protective factors that enhance resilience of circumpolar Indigenous youth to a range of stresses (Petrasek MacDonald et al., 2013b). The Likert questions were specifically focused on discerning which protective factors participants experienced throughout the PV process and to what degree, while the open-ended questions were designed to collect a more detailed narrative understanding of how these factors were supported, and what they meant for the youth. The two types of questions also provided complementary qualitative and quantitative data that strengthen the results. The community member interviews used 12 openended questions, which were also conducted conversationally. Examples of the types of questions asked of community members included the following: "Do you think the video was an effective way to connect with the community and culture of Rigolet? Why or why not?" "Do you think that video is a good teaching tool to illustrate the concerns perceived by youth? Why?" and "Do you think video is a good discussion starter about ways to respond and adapt to the changes felt by the youth and/or community?" 
TABLE 3. Example of questions asked under each section in the youth participant interview guide. In the last section, youth responded to each statement on a scale from "strongly agree" to "strongly disagree," with options of "I don't know" or "Refuse."

\begin{tabular}{|c|c|}
\hline Section & Examples of questions \\
\hline Film content & $\begin{array}{l}\text { Tell me about the video you made. } \\
\text { Tell me about the footage that you wanted shot and included. } \\
\text { What is the main message you wanted the film to convey? }\end{array}$ \\
\hline Film process & $\begin{array}{l}\text { How would you describe the experience of making the film? } \\
\text { Is there anything you would change about the film? } \\
\text { Did you feel you had enough skills, knowledge, and support to make the film you and your peers wanted to make? } \\
\text { Would you make a film again if you had another chance? }\end{array}$ \\
\hline Film evaluation & $\begin{array}{l}\text { What do you think about your film? } \\
\text { Do you think the film is a good way to teach people from Rigolet and from other communities about this community? Why or why not? } \\
\text { How did you feel when your film was screened for the community? }\end{array}$ \\
\hline Protective factors & $\begin{array}{l}\text { The project made me feel useful in my community. } \\
\text { I developed deeper relationships throughout the process with my peers. } \\
\text { I received a lot of praise from my community throughout the process. } \\
\text { I felt ownership over the project. }\end{array}$ \\
\hline
\end{tabular}

\section{Data Analysis}

The interviews were qualitatively analyzed using a constant comparative method, in which codes were continuously compared within and between interviews (Bradley et al., 2007). Analysis consisted of creating project memos for each interview to document quotes, common words, and emerging ideas and relationships, which were then reviewed collectively to group key quotes, words, and ideas under descriptive nested open codes (Miles and Huberman, 1994; Denzin and Lincoln, 2005). While the codes were not developed a priori, it became clear early on in the analytical process that the codes emerging more strongly described or were connected to protective factors. Therefore, as analysis continued, the data took shape around protective factors and pathways. The Likert data provided direct, quantitative data on protective factors, while a more nuanced and localized understanding of protective factors and the pathways that led to these factors came from the in-depth interview data. Concept maps were created to illustrate relationships and overlap between codes in order to identify and compare key concepts and overarching codes. This process resulted in expanding and collapsing the list of codes continuously as new ideas emerged until key themes that best reflected the data were identified. Likert scale data were analyzed using frequency counts. Participant verification was done in February 2014 through meetings with youth participants and community members to ensure that the findings reflected and represented the local and cultural context from which they emerged.

\section{RESULTS}

Upon reflecting on certain aspects of the PV workshop, as well as the process as a whole, youth participants, parents, teachers, and other community members described experiences, feelings, and observations that are synonymous with protective factors that are known to enhance resilience of circumpolar Indigenous youth (Petrasek MacDonald et al., 2013b) and thus can be connected to fostering the capacity to adapt to climate-related challenges. Six of these documented protective factors strongly emerged: autonomy and empowerment; pride in self; connecting generations; community pride; communication and reflection; and meaningful opportunities to be involved.

\section{Autonomy and Empowerment}

Six of the seven youth participants either strongly agreed $(n=2)$ or agreed $(n=4)$ that the video workshop had enhanced their self-esteem throughout the process. All participants either strongly agreed $(n=5)$ or agreed $(n=2)$ that they felt a sense of ownership over the project. When describing what contributed to developing feelings of ownership, youth noted various pathways, such as feeling in control at all stages of the filmmaking process, feeling that their interests and ideas directed the project, and being trusted with the equipment. As one female participant described,

It was fantastic! There's a lot of fun activities to do in the film...like sliding...it's like you take control of the camera...you just like film anything. Well first you have to work it out. But then you're like "Oh if we want to go play outside" then [the facilitators] will be like "Yah ok let's try it!"

Parents and teachers observed and commented on autonomy as one of the important benefits from the workshop. For example, one teacher voiced the view that the greatest impact of the project for the youth participants was

getting them to make the video and to know they did it. Not something done for them or thrown together or handed to them. They worked on it, and they did it and 
then got to show everyone what they did, and they got good feedback. I think that's the biggest thing out of it.

Beyond providing a feeling of ownership, the project also fostered empowerment. As one of the facilitators from Konek Productions said, "My main goal here was to let the younger people know [and understand] that as long as you stick with something you want to do, it's something you can do if you work on it." The ability of the project to empower youth was also noted by teachers who saw the students taking charge of the project. One teacher said that the project "Gets the kids saying 'OK, I can do this,' and they did do it very well."

\section{Pride in Self}

All participants strongly agreed $(n=6)$ or agreed $(n=1)$ using the Likert scale that participating in the project made them feel proud and strongly agreed $(n=3)$ or agreed $(n=$ 4) that participating in the project made them feel special. When asked if they received a lot of praise throughout the process from teachers and friends, all participants strongly agreed $(n=2)$ or agreed $(n=5)$. With respect to receiving praise from family and the community, the Likert results were similar; one youth disagreed $(n=1)$ and the rest agreed ( $\mathrm{n}=2$ for family, $\mathrm{n}=5$ for community) or strongly agreed ( $\mathrm{n}=4$ for family, $\mathrm{n}=1$ for community). These findings from the Likert questions connect to other feelings and experiences the student participants described. For example, many said they developed more confidence in making videos, in using a camera, and in themselves. One female participant described how her confidence in her filmmaking skills has grown noting, "I've learned more about technology now so I won't be like 'I can't do this' and now I'll be like 'Oh I know what to do!'”

Parents and teachers recognized confidence and pride fostered in the youth participants, particularly at the screening, with comments such as, "There was great pride. They stood tall. You could see...cause I tend to watch them as they watch themselves on the screen as well...so just observing them you could see the smiles." The self-pride fostered through the process was recognized as one of the key benefits of the project. As one teacher commented, "If you talk to those kids today then I think they'll say 'I'm proud of what I've done, what we've done'-individually and as a group - which is important...affirmation of that."

In addition to learning and enhancing skills and filmmaking knowledge, and gaining self-confidence, other pathways that led to feeling pride in self included the continuous communication with peers, family, and teachers throughout the process; having a tangible, visual product of the effort and time that went into the project; and having an opportunity to showcase skills, talents, and knowledge that received praise and recognition at the well-attended screening. Indeed, there was widespread community representation at the screening, with grandparents, parents, siblings, friends, teachers, and other community members coming to support the youth and watch their video. The praise and affirmation that the youth received at the community screening was a particularly important pathway that contributed to fostering pride in their work and in themselves.

\section{Connecting Generations}

Using the Likert scale, the majority of the participants strongly agreed $(n=2)$ or agreed $(n=3)$ that the project gave them a chance to interact with people in the community in a different way than usual, while the other two participants disagreed $(n=1)$ or chose the option "I don't know" $(\mathrm{n}=1)$. While four participants strongly agreed $(n=2)$ or agreed $(n=2)$ that they developed deeper relationships with other community members throughout the process, the others disagreed $(n=3)$. It is worth noting that all seven participants disagreed $(n=7)$ that they had a lot of opportunity to communicate and interact specifically with Elders throughout the process. Rather, the communication and interaction with older community members reported by youth was with middle-aged adults, such as parents and teachers.

Sharing the film at the screening and having conversations about the film afterwards - particularly with older community members such as parents, teachers, and other middle-aged adults - provided an opportunity for the youth to connect with adults in their community. For example, one female participant recounted a conversation with an older community member after the screening, "He was asking if it was fun to make, how you made it, what did you do, what parts did you cut out." Many of the older audience members said that having the film come from the voices of youth in their community made the resulting video all the more interesting to them.

The creation of opportunity and space for conversations between the youth and older generations in the community was recognized and appreciated as a benefit of the film, but it was also reported as a benefit of the process. For example, the participants spoke to teachers and parents about the progress of the film throughout the project. While the communication and interaction with older generations as part of the project were limited to the community screening, the young people expressed great interest in having more opportunities in the future to connect with adults and Elders in particular through video formats. The option of interviewing adults as part of another youth-led video was suggested by youth and parents.

\section{Community Pride}

Community pride largely stemmed from feeling support from the community, which extended into the participatory video process: all participants strongly agreed $(n=7)$ on the Likert scale that the community supported the project, and the student discussions supported these findings, indicating specific pathways such as attendance at the screening and the free use of space and equipment that expressed community support. They also showed that they felt support from 
the community in their interviews and in the film itself (e.g., see time 3:00-3:15 in the film).

The expression of community pride was at the core of the film's story and message. Reflecting on community support, sharing experiences of living in the community, and expressing community pride and pride in place are ways to disprove negative stereotypes of small, remote, northern communities and foster community pride. When asked what message they hoped people would take away from the film, participants said things like, "I'd like people to see how good our town is and how nice the people are around here," and,

How life in Rigolet turns out to be. Usually like when you tell someone about Rigolet, and it's just like a small community, they'll be like 'Oh that sounds so boring. There's like nothing to do. You don't have parks or restaurants or anything like that.' And when you watch the video you learn that there's actually so much to do.

In particular, youth felt great pride in sharing the tradition of going out for a boil-up (e.g., see time 3:53-5:00 in the film) with the out-of-town facilitators and with the audience, and as one audience member remarked "[The] intimacy of boil-up seemed to be a focal point for a lot of the kids, what they take pride in and what they enjoy doing." Seeing the community pride expressed by youth in the film fostered community pride in the audience. After seeing the film, one mother and Rigolet resident who has lived in town her entire life said that it was great to see "our little community" highlighted in the film and that she enjoyed it because, "it's your own children there, your own community."

\section{Communication and Reflection}

Opportunities for communication, interaction, and discussion occurred both throughout the process and via the film. When asked to rank on a Likert scale whether there were lots of opportunities to communicate and interact with family, all youth participants strongly agreed $(n=1)$ or agreed $(n=6)$. Six of the seven participants strongly agreed $(n=5)$ or agreed $(n=1)$ that there were lots of opportunities to communicate and interact with their peers throughout the project, while the other participant chose the option "I don't know."

Both youth and adults recognized the film as an interesting and effective method for communicating youth perspectives, knowledge, and experience. After viewing the final film, parents, teachers, and community members commented on the ability of the video to provide insight into the lives of their children and other youth in Rigolet. As one mother commented, by watching the video she "[got] a chance to see the things they like to do and hear from them and see the way they interact." This demonstrates the ability of a youth-led film to share insight into the lives, perspectives, skills, and capabilities of its young creators; such information, that otherwise might not be available, could greatly enhance adaptation research which, to date, has not widely included youth voices.

Youth-led video in particular was cited as a useful knowledge-sharing tool that could inform youth programming in northern communities. For example, one participant said, "The film explains what we do in Rigolet when it's boring;" this information was of particular interest to one of the parents who has reflected on the activities available for her children and other young people in Rigolet: "I think to myself there isn't much for them to be doing." One youth participant commented that video is a fun alternative itself if you cannot go out on the land or if you are bored.

The ability of the filmmaking process and the final film to inspire reflection was also noted by participants. For example, one participant said, "A lot of people are going to see it and then they'll start thinking about [the information in the film]." The process and film also provided an opportunity for participants themselves to reflect. As one parent commented, "For them [the youth participants] it was a learning experience [that] gave them a chance to think about things they do in the community."

\section{Meaningful Opportunities to be Involved}

Parents noted the ability of video technology to involve and engage their children in a meaningful activity. For example, one parent felt that turning her daughter's interest in filmmaking toward land activities might encourage her to get outside more: "If [my daughter] were to make a video about [the cabin] she would be more interested in going." Based on the success of video engaging youth in the community, many adults saw potential of youth-created video as a means of promoting youth participation, involvement, and input in local or regional issues. Both of the community facilitators noted that video is a good way to get youth to open up about their thoughts, opinions, ideas, and feelings: "[It's a] good way to get youth talking about things they wouldn't normally talk about."

When discussing the use of video to highlight the youth voice, a parent who was also one of the community facilitators emphasized that video is a meaningful way to involve youth in community issues,

[Making a video] would be a chance for them to talk about things they might not always think about or talk about together and then it would make everyone think about it, because we don't always think that the kids even know anything let alone that they'd have something valuable to offer, you know what I mean? Which is really bad on our part but that's just the way society is I guess. And then it would help other kids to think about it if they see their peers talking about this.

In particular, community members also saw great potential in doing video to get youth involved with the issue of climate change. When asked about youth and climate change in the interviews, many community members 
pointed out that climate change is not at the forefront of the minds of youth. One teacher said,

I think if you spark the conversation [about climate change] then you will get the results...I don't know that they've been challenged or empowered enough to take [climate change] on as a cause; there's not been a call to action, but they would certainly respond to a conversation.

Parents and teachers think climate change is "something important for them to start thinking about" and "be empowered to take on as a cause" and, as such, this can be an appropriate issue to address with youth. Community members also had ideas about the ways in which participatory video could be used with youth on climate adaptation work such as sparking discussion and conversation about changes, impacts, and responses in a fun and positive way, and translating knowledge by youth filming interviews with grandparents or Elders about their childhood and how their activities have changed. As one parent commented, "I think [video] would be a good way to initiate their thinking to climate change. A good way to bring it up in not such a serious or daunting way and it would get the kids thinking about the issues."

\section{DISCUSSION AND CONCLUSION}

Participatory video is an important method for engaging youth in research and educational processes. It resonates with the interests of young people and uses technology to access, explore, and vocalize their thoughts and feelings and showcase their skills, interests, knowledge, perspectives, ideas, experience, and capabilities (Allan, 2012). This method also provides training and capacity development benefits by offering a learning and communication platform that can create opportunities for collaboration with youth in a research setting and encourages the participation of young people in planning and decision making (Lunch, 2007; Milne et al., 2012). As this case study demonstrates, one important characteristic of PV is its ability to link to known protective factors that may help to foster youth resilience and enhance adaptive capacities.

Embedded in the process of PV are multiple pathways to known protective factors that underpin circumpolar Indigenous youth resilience. For example, the conversation, learning, and relationship building present throughout the process of creating a PV (Ferreira, 2006) can serve to further connect youth with adults or elderly community members. By connecting generations, PV can both build on and strengthen existing social networks, including kinship, which continue to be of great importance in Inuit communities and support opportunities for knowledge sharing between generations, which is a key characteristic of adaptive capacity to climate change impacts (Ford et al., 2006, 2010; Pearce et al., 2011).
Indeed, social connectedness is crucial for promoting resilience and adaptability to climate change, engaging people with various types of expertise in adaptation planning, ensuring that concerns are represented and addressed, and increasing local capacity for community action on adaptation efforts (Ford et al., 2006, 2010; Ebi and Semenza, 2008). The disconnect between generations that has been observed and experienced in the North has been associated with a breakdown of knowledge transfer, weakening of land-based skills, and enhanced vulnerability among younger generations to climate change impacts (Ford et al., 2006, 2008, 2010; Pearce et al., 2010, 2011; Heyes, 2011; Kral et al., 2011). One priority for enhancing adaptive capacity is "supporting the teaching and transmission of traditional skills" (Ford et al., 2010:187), and this priority, along with developing strong social networks can be addressed using PV. This case study shows that PV, by having youth share their film with older generations, can foster intergenerational relationships. Participants in this study also identified potential for PV to include older community members in the process by having youth do film interviews with adults or Elders which could also provide opportunities for knowledge sharing.

Having meaningful opportunities to be involved within one's community is another protective factor known to enhance the resilience of circumpolar Indigenous youth by strengthening relationships in the community and providing opportunities for praise and feeling ownership (Mohatt et al., 2004; Allen et al., 2006; Ford et al., 2012; DeCou et al., 2013). In addition, community involvement is one way of increasing social capital and strengthening social networks, important determinants of adaptive capacity for climate change (Ebi and Semenza, 2008). PV not only provides an opportunity for youth involvement in and of itself, but can also be a means of involving youth in other community issues, such as adaptation planning. Suarez et al. (2008:96) describe participant-led video as an "ideal mediation space to bring together the multiple stakeholders needed to address climate change." Youth are important stakeholders in adaptation discussions, and youth-led PV can be a way to communicate perspectives, to inform priorities, harness the innovation and creativity of youth for developing adaptation strategies, and act as a gateway for discussion between youth, community leaders, researchers, and government representatives. In this sense, not only does active youth participation benefit adaptation efforts, but also the act of participating and being engaged can simultaneously enhance individual youth adaptive capacity by supporting protective factors such as staying busy and having positive role models. Furthermore, providing opportunities for young Inuit to be meaningfully involved in community issues using PV demonstrates recognition and appreciation for youth that can lead to autonomy and foster community pride and self-pride, other documented protective factors that enhance circumpolar Indigenous youth mental health and well-being (Bals et al., 2011; Wexler et al., 2013; Wexler, 2014) and thus may contribute to enhancing resilience 
and adaptive capacities for dealing with climate change impacts.

The PV process provides many opportunities for continuous communication and interaction through collaborating with peers on creating the film, involving others in the filming, and discussing the project with friends, family, and community members. Communication and interaction within one's family and community are known protective factors (Mohatt et al., 2004; Wexler and Goodwin, 2006; Kral et al., 2011); whether this protective nature extends to communication and interaction between communities is less clear, but it may be likely. For example, in an adaptation context, despite great variability across northern communities with respect to the changes being experienced, the existing challenges faced, and the ways in which people can best adapt, there is still much that can be learned from one another about best practices in adaptation (Ford and Pearce, 2012). Inuit youth in communities across the North could be engaged in creating videos to document adaptation ideas, programs, and success stories that could foster opportunities for sharing, reflection, and consultation on community initiatives, promote action at a local and regional level, and, perhaps most importantly, connect youth across the North to other people who face similar challenges.

Sharing videos could also provide an opportunity for youth to advocate for their communities and express community pride (Suarez et al., 2008). Indeed, communities play a crucial role in fostering youth resilience and adaptive capacities (DeCou et al., 2013; Wexler et al., 2013, 2014; Wexler, 2014). Specifically, feeling a sense of belonging to a supportive, caring, and connected community is at the core of Indigenous cultural values. This feeling greatly enhances circumpolar Indigenous resilience (Mohatt et al., 2004; Wexler and Goodwin, 2006; DeCou et al., 2013; Wexler et al., 2013; Wexler, 2014) and cultivates strong communities that support participation and cooperative, community-led action which has been identified as important to building adaptive capacity (IPCC, 2014). Not only can the process of PV foster these feelings, but the video itself can also express the support youth feel from their community, as was the case in this study.

At the same time, it is important to recognize the challenges faced and the lessons learned along the way in this exploratory project. For example, the two-week timeframe limited opportunities for in-depth planning, training, reviewing footage, and developing deeper relationships between and among participants, as well as between youth and facilitators. Furthermore, a higher degree of facilitation and guidance was required than initially was anticipated. While the participants were the directors of the process, the amount of flexibility versus direction was constantly shifting. Working with flexibility led to another challenging aspect - one which has been discussed by other researchers using participant-led methods - which was the struggle to maintain research interests while using a method controlled by participants (Evans et al., 2009; Lomax et al., 2011; Mistry and Berardi, 2012). An intentional project goal, and the substance of PV, was to emphasize participant control; however, this emphasis can lead to a substantial shift away from the original research topic. In this case, our interest was in gathering youth priorities and perspectives on community climate change adaptation, but the final film that emerged was not related to climate change; instead, it showcased the lives of youth in Rigolet, specifically their winter activities. Since this change in topic was anticipated and understood from the outset, the research team was prepared to reconcile the differences in interests by finding ways to connect the topic participants chose to research themes of climate change adaptation and youth resilience. In this case, we moved forward focusing on protective factors within the process itself that still informed our interest in exploring youth adaptation strategies to climate change but from a different angle (i.e., factors important to incorporate into adaptation research, policy, and programs that aim to enhance resilience and adaptive capacity) compared to our initial intent of directly discussing adaptation strategies with youth. The project demonstrates how the challenges of managing people and losing control are important aspects of the PV experience that can open interesting research avenues and lead to rich knowledge-sharing opportunities that might otherwise not be accessed (Evans et al., 2009; Milne et al., 2012).

Although this case study shows promise for using PV to engage youth in northern adaptation research in a way that connects with protective factors important for youth resilience and adaptive capacities, the work is preliminary and more research is needed to further investigate the application of PV in adaptation research and planning. Another avenue for further study is the capacity of other visual, participatory, youth-led methods to create similar opportunities and outcomes around youth resilience. Are there common characteristics between methods that elicit pathways to protective factors? One likely important trait of such methods is the adaptability to incorporate and make use of the latest technologies and respond to the current context, needs, interests and skills of youth participants so that they can use the method in their own way (Schaefer, 2011; White and Bushin, 2011). Doing it differently and specifically customizing to the participants and context may help to avoid fatigue and saturation.

As the need for targeted adaptation planning and research increases with the rapid rate of change in the North and globally, encouraging the participation and leadership of youth is crucial (Petrasek MacDonald et al., 2013a). By meaningfully engaging youth and consciously connecting to known youth protective factors, such as through the use of visual methods like PV, adaptation research can incorporate youth voices and perspectives while fostering youth that are resilient, motivated to adapt, and capable of dealing with the socio-economic, cultural, physical and mental health impacts of climate change. Developing a healthy, actively involved, and resilient youth population can contribute to fostering healthy communities and a healthy future. 


\section{ACKNOWLEDGEMENTS}

We are extremely grateful to the community of Rigolet, in particular the young people who worked on this project with us, the parents that volunteered their time to accompany us on our boil-up, and all the community members who showed their support throughout the video workshop. Many thanks to Tom Mugford and the staff at the Northern Lights Academy; to the Rigolet Inuit Community Government; to Jordan and Curtis Konek from Konek Productions, along with Inez Shiwak and Marilyn Baikie of the My Word Storytelling and Digital Media Lab, for help facilitating the workshop and other assistance; and to the Nunatsiavut Department of Health and Social Development, the Native Spirit Youth Centre in Rigolet, Air Labrador, and First Air for their support of this project. We are very thankful for support from the Inuit Traditional Knowledge for Adapting to the Health Effects of Climate Change project (IK-ADAPT), the Inuit Mental Health Adaptation to Climate Change project (IMHACC), and the Indigenous Health Adaptation to Climate Change project (IHACC). We also thank Anna Bunce for her help in preparing the manuscript. Finally, we are grateful for a grant from Health Canada's First Nations and Inuit Health Branch and the funding provided through the Social Sciences and Humanities Research Council (SSHRC), ArcticNet, the CIHR Applied Public Health Chair, the Nasivvik Centre for Inuit Health and Changing Environments, and the Royal Canadian Geographic Society.

\section{REFERENCES}

Allan, A. 2012. Power, participation and privilege - methodological lessons from using visual methods in research with young people. Sociological Research Online 17(3): 8.

http://dx.doi.org/10.5153/sro.2662

Allen, J., Mohatt, G.V., Rasmus, S.M., Hazel, K.L., Thomas, L., and Lindley, S. 2006. The tools to understand: Community as co-researcher on culture-specific protective factors for Alaska Natives. Journal of Prevention \& Intervention in the Community 32(1-2):41-59.

http://dx.doi.org/10.1300/J005v32n01_04

Allen, J., Hopper, K., Wexler, L., Kral, M., Rasmus, S., and Nystad, K. 2014. Mapping resilience pathways of Indigenous youth in five circumpolar communities. Transcultural Psychiatry 51(5):601-631.

http://dx.doi.org/10.1177/1363461513497232

Alrutz, M. 2013. Sites of possibility: Applied theatre and digital storytelling with youth. Research in Drama Education: The Journal of Applied Theatre and Performance 18(1):44-57. http://dx.doi.org/10.1080/13569783.2012.756169

Bals, M., Turi, A.L., Skre, I., and Kvernmo, S. 2010. Internalization symptoms, perceived discrimination, and ethnic identity in Indigenous Sami and non-Sami youth in Arctic Norway. Ethnicity \& Health 15(2):165-179. http://dx.doi.org/10.1080/13557851003615545

2. 2011. The relationship between internalizing and externalizing symptoms and cultural resilience factors in Indigenous Sami youth from Arctic Norway. International Journal of Circumpolar Health 70(1):37-45.
Bird, S., Wiles, J.L., Okalik, L., Kilabuk, J., and Egeland, G.M. 2009. Methodological consideration of story telling in qualitative research involving Indigenous peoples. Global Health Promotion 16(4):16-26.

http://dx.doi.org/10.1177/1757975909348111

Blazek, M., and Hraňová, P. 2012. Emerging relationships and diverse motivations and benefits in participatory video with young people. Children's Geographies 10(2):151 - 168 . http://dx.doi.org/10.1080/14733285.2012.667917

Bradley, E.H., Curry, L.A., and Devers, K.J. 2007. Qualitative data analysis for health services research: Developing taxonomy, themes, and theory. Health Services Research 42(4): $1758-1772$. http://dx.doi.org/10.1111/j.1475-6773.2006.00684.x

Brody, H., dir. 1976. A people's land: Eskimos of Pond Inlet [Documentary]. United Kingdom: ITV Granada.

Cameron, E.S. 2012. Securing Indigenous politics: A critique of the vulnerability and adaptation approach to the human dimensions of climate change in the Canadian Arctic. Global Environmental Change 22(1):103-114.

http://dx.doi.org/10.1016/j.gloenvcha.2011.11.004

Castleden, H., Morgan, V.S., and Lamb, C. 2012. "I spent the first year drinking tea": Exploring Canadian university researchers' perspectives on community-based participatory research involving Indigenous peoples. The Canadian Geographer 56(2):160- 179 .

http://dx.doi.org/10.1111/j.1541-0064.2012.00432.x

Chonody, J., Ferman, B., Amitrani-Welsh, J., and Martin, T. 2013. Violence through the eyes of youth: A photovoice exploration. Journal of Community Psychology 41(1):84-101.

http://dx.doi.org/10.1002/jcop.21515

Cunsolo Willox, A., Harper, S.L., Edge, V.L., 'My Word': Storytelling and Digital Media Lab, and the Rigolet Inuit Community Government. 2012a. Storytelling in a digital age: Digital storytelling as an emerging narrative method for preserving and promoting Indigenous oral wisdom. Qualitative Research 13(2):127-147.

http://dx.doi.org/10.1177/1468794112446105

Cunsolo Willox, A., Harper, S.L., Ford, J.D., Landman, K., Houle, K., Edge, V.L., and the Rigolet Inuit Community Government. 2012b. "From this place and of this place:" Climate change, sense of place, and health in Nunatsiavut, Canada. Social Sciences \& Medicine 75(3):538-547.

http://dx.doi.org/10.1016/j.socscimed.2012.03.043

Cunsolo Willox, A., Harper, S.L., Edge, V.L., Landman, K., Houle, K., Ford, J.D., and the Rigolet Inuit Community Government. 2013a. The land enriches the soul: On climatic and environmental change, affect, and emotional health and well-being in Rigolet, Nunatsiavut, Canada. Emotion, Space, and Society 6:14-24.

http://dx.doi.org/10.1016/j.emospa.2011.08.005

Cunsolo Willox, A., Harper, S.L., Ford, J.D., Edge, V.L., Landman, K., Houle, K., Blake, S., and Wolfrey, C. 2013b. Climate change and mental health: An exploratory case study from Rigolet, Nunatsiavut, Canada. Climatic Change 121(2):255-270.

http://dx.doi.org/10.1007/s10584-013-0875-4 
de Block, L., and Buckingham, D., 2008. Global children, global media: Migration, media and childhood. Basingstoke, United Kingdom: Palgrave Macmillan.

DeCou, C.R., Skewes, M.C., and López, E.D.S. 2013. Traditional living and cultural ways as protective factors against suicide: Perceptions of Alaska Native university students. International Journal of Circumpolar Health 72: 20968. http://dx.doi.org/10.3402/ijch.v72i0.20968

de Lange, N., and Geldenhuys, M.M. 2012. Youth envisioning safe schools: A participatory video approach. South African Journal of Education 32(4):494-511.

Denzin, N.K., and Lincoln, Y.S., eds. 2005. The Sage handbook of qualitative research, $3^{\text {rd }}$ ed. Thousand Oaks, California: Sage Publications.

Ebi, K.L., and Semenza, J.C. 2008. Community-based adaptation to the health impacts of climate change. American Journal of Preventive Medicine 35(5):501 - 507. http://dx.doi.org/10.1016/j.amepre.2008.08.018

Evans, M., Foster, S., Corbett, J., Dolmage, E., Gervais, J., Mann, R., and Romano, Z. 2009. Representation in participatory video: Some considerations from research with Métis in British Columbia. Journal of Canadian Studies 43(1):87-108.

Ferreira, G.A. 2006. Participatory video for policy development in remote Aboriginal communities. PhD thesis, University of Guelph, Guelph, Ontario.

Ford, J.D. 2008. Supporting adaptation: A priority for action on climate change for Canadian Inuit. Sustainable Development Law \& Policy 8(3):25-29, 64.

. 2009. Dangerous climate change and the importance of adaptation for the Arctic's Inuit population. Environmental Research Letters 4(2): 024006. http://dx.doi.org/10.1088/1748-9326/4/2/024006

Ford, J.D., and Furgal, C. 2009. Foreword to the special issue: Climate change impacts, adaptation and vulnerability in the Arctic. Polar Research 28(1):1-9. http://dx.doi.org/10.1111/j.1751-8369.2009.00103.x

Ford, J.D., and Pearce, T. 2010. What we know, do not know, and need to know about climate change vulnerability in the western Canadian Arctic: A systematic literature review. Environmental Research Letters 5(1): 014008. http://dx.doi.org/10.1088/1748-9326/5/1/014008

- 2012. Climate change vulnerability and adaptation research focusing on the Inuit subsistence sector in Canada: Directions for future research. The Canadian Geographer 56(2):275-287. http://dx.doi.org/10.1111/j.1541-0064.2012.00418.x

Ford, J.D., Smit, B., and Wandel, J. 2006. Vulnerability to climate change in the Arctic: A case study from Arctic Bay, Nunavut. Global Environmental Change 16(2):145-160. http://dx.doi.org/10.1016/j.gloenvcha.2005.11.007

Ford, J.D., Smit, B., Wandel, J., Allurut, M., Shappa, K., Ittusarjuat, H., and Qrunnut, K. 2008. Climate change in the Arctic: Current and future vulnerability in two Inuit communities in Canada. The Geographical Journal 174(1):45-62. http://dx.doi.org/10.1111/j.1475-4959.2007.00249.x
Ford, J.D., Pearce, T., Duerden, F., Furgal, C., and Smit, B. 2010. Climate change policy responses for Canada's Inuit population: The importance of and opportunities for adaptation. Global Environmental Change 20(1):177-191.

http://dx.doi.org/10.1016/j.gloenvcha.2009.10.008

Ford, J.D., Cunsolo Willox, A., Chatwood, S., Furgal, C., Harper, S., Mauro, I., and Pearce, T. 2014. Adapting to the effects of climate change on Inuit health. American Journal of Public Health 104(S3): e9-e17. http://dx.doi.org/10.2105/AJPH.2013.301724

Ford, T., Rasmus, S., and Allen, J. 2012. Being useful: Achieving Indigenous youth involvement in a community-based participatory research project in Alaska. International Journal of Circumpolar Health 71: 18413.

http://dx.doi.org/10.3402/ijch.v71i0.18413

Foster-Fishman, P.G., Law, K.M., Lichty, L.F., and Aoun, C. 2010. Youth ReACT for social change: A method for youth participatory action research. American Journal of Community Psychology 46(1-2):67-83. http://dx.doi.org/10.1007/s10464-010-9316-y

Garrett, B.L. 2010. Videographic geographies: Using digital video for geographic research. Progress in Human Geography 35(4):521-541.

http://dx.doi.org/10.1177/0309132510388337

Genuis, S.K. 2013. Participatory video: A tool for engaging and empowering Aboriginal youth (Abstract). International Journal of Qualitative Methods 12:706.

Guillemin, M., and Drew, S. 2010. Questions of process in participant-generated visual methodologies. Visual Studies 25(2):17-188. http://dx.doi.org/10.1080/1472586X.2010.502676

Harper, S.L., Edge, V.L., Cunsolo Willox, A., and the Rigolet Inuit Community Government. 2012. 'Changing climate, changing health, changing stories' profile: Using an EcoHealth approach to explore impacts of climate change on Inuit health. EcoHealth 9(1):89- 101. http://dx.doi.org/10.1007/s10393-012-0762-x

Healey, G.K., Magner, K.M., Ritter, R., Kamookak, R., Aningmiuq, A., Issaluk, B., Mackenzie, K., Allardyce, L., Stockdale, A., and Moffit, P. 2011. Community perspectives on the impact of climate change on health in Nunavut, Canada. Arctic 64(1):89-97. http://dx.doi.org/10.14430/arctic4082

Heath, J., dir. 2012. People of a Feather [Documentary]. Canada: Joel Heath.

Heyes, S.A. 2011. Cracks in the knowledge: Sea ice terms in Kangiqsualujjuaq, Nunavik. Canadian Geographer 55(1):69-90. http://dx.doi.org/10.1111/j.1541-0064.2010.00346.x

Hung, C.-M., Hwang, G.-J., and Huang, I. 2012. A projectbased digital storytelling approach for improving students' learning motivation, problem-solving competence and learning achievement. Educational Technology \& Society 15(4):368-379.

IPCC (Intergovernmental Panel on Climate Change). 2014. Climate change 2014: Impacts, adaptation, and vulnerability. Contribution of Working Group II to the Fifth Assessment Report of the Intergovernmental Panel on Climate Change. 
Iseke, J., and Moore, S. 2011. Community-based Indigenous digital storytelling with elders and youth. American Indian Culture and Research Journal 35(4):19-38.

Jackson, A.Y., and Mazzei, L.A., eds. 2009. Voice in qualitative inquiry: Challenging conventional, interpretive, and critical conceptions in qualitative research. London: Routledge.

Jardine, C.G., and James, A. 2012. Youth researching youth: Benefits, limitations and ethical considerations within a participatory research process. International Journal of Circumpolar Health 71: 18415. http://dx.doi.org/10.3402/ijch.v71i0.18415

Kindon, S. 2003. Participatory video in geographic research: A feminist practice of looking? Area 35(2):142 - 153. http://dx.doi.org/10.1111/1475-4762.00236

Kirmayer, L.J., Boothroyd, L.J., and Hodgins, S. 1998. Attempted suicide among Inuit youth: Psychological correlates and implications for prevention. Canadian Journal of Psychiatry 43(8):816-822.

Kirmayer, L.J., Dandeneau, S., Marshall, E., Phillips, M.K., and Williamson, K.J. 2011. Rethinking resilience from Indigenous perspectives. Canadian Journal of Psychiatry 56(2):84-91.

Kral, M.J., Idlout, L., Minore, J.B., Dyck, R.J., and Kirmayer, L.J. 2011. Unikkaartuit: Meanings of well-being, unhappiness, health, and community change among Inuit in Nunavut, Canada. American Journal of Community Psychology 48(34):426-438. http://dx.doi.org/10.1007/s10464-011-9431-4

Krupnik, I., and Jolly, D., eds. 2002. The earth is faster now: Indigenous observations of Arctic environmental change. Fairbanks: Arctic Research Consortium of the United States.

Kunuk, Z., and Mauro, I., dirs. 2010. Qapirangajuq: Inuit knowledge and climate change [Documentary]. Igloolik, Nunavut: IsumaTV.

Kvale, S. 1996. InterViews: An introduction to qualitative research interviewing. Thousand Oaks, California: Sage Publications.

Lehti, V., Niemelä, S., Hoven, C., Mandell, D., and Sourander, A. 2009. Mental health, substance use, and suicidal behaviour among people in the Arctic: A systematic review. Social Science \& Medicine 69(8):1194-1203. http://dx.doi.org/10.1016/j.socscimed.2009.07.045

Lomax, H., Fink, J., Singh, N., and High, C. 2011.The politics of performance: Methodological challenges of researching children's experiences of childhood through the lens of participatory video. International Journal of Social Research Methodology 14(3):231-243.

http://dx.doi.org/10.1080/13645579.2011.563622

Lunch, C. 2007. The most significant change: Using participatory video for monitoring and evaluation. Participatory Learning and Action 56:28-32. London: International Institute for Environment and Development.

Luttrell, W. 2010. 'A camera is a big responsibility': A lens for analyzing children's visual voices. Visual Studies 25(3):224-234.

http://dx.doi.org/10.1080/1472586X.2010.523274

Mayer, V. 2000. Capturing cultural identity/creating community: A grassroots video project in San Antonio, Texas. International Journal of Cultural Studies 3(1):57-78. http://dx.doi.org/10.1177/136787790000300104
McClymont Peace, D., and Myers, E. 2012. Community-based participatory process - climate change and health adaptation program for northern First Nations and Inuit in Canada. International Journal of Circumpolar Health 71(1): 18412. http://dx.doi.org/10.3402/ijch.v71i0.18412

Miles, M.B., and Huberman, A.M. 1994. Qualitative data analysis: An expanded sourcebook, 2nd ed. Thousand Oaks, California: Sage Publications.

Milne, E.-J., Mitchell, C., and de Lange, N., eds. 2012. Handbook of participatory video. Lanham, Maryland: AltaMira Press.

Mistry, J., and Berardi, A. 2012. The challenges and opportunities of participatory video in geographical research: Exploring collaboration with Indigenous communities in the North Rupununi, Guyana. Area 44(1):110-116.

http://dx.doi.org/10.1111/j.1475-4762.2011.01064.x

Mohatt, G.V., Rasmus, S.M., Thomas, L., Allen, J., Hazel, K., and Hensel, C. 2004. "Tied together like a woven hat:" Protective pathways to Alaska Native sobriety. Harm Reduction Journal 1: 10 . http://dx.doi.org/10.1186/1477-7517-1-10

Moletsane, R., Mitchell, C., de Lange, N., Stuart, J., Buthelezi, T., and Taylor, M. 2009. What can a woman do with a camera? Turning the female gaze on poverty and HIV and AIDS in rural South Africa. International Journal of Qualitative Studies in Education 22(3):315-331. http://dx.doi.org/10.1080/09518390902835454

Nickels, S., Furgal, C., Buell, M., and Moquin, H. 2006. Unikkaaqatigiit - putting the human face on climate change: perspectives from Inuit in Canada. Ottawa: Joint publication of Inuit Tapiriit Kanatami, Nasivvik Centre for Inuit Health and Changing Environments at Université Laval and the Ajunnginiq Centre at the National Aboriginal Health Organization.

Ohashi, Y., Ohashi, K., Meskanen, P., Hummelin, N., Kato, F., and Kynäslahti, H. 2012. What children and youth told about their home city in digital stories in ' $\mathrm{C}$ my city!'. Digital Creativity 23(2):126-135.

http://dx.doi.org/10.1080/14626268.2012.709942

Pain, R. 2004. Social geography: Participatory research. Progress in Human Geography 28(5):652-663. http://dx.doi.org/10.1191/0309132504ph511pr

. 2008. Ethical possibilities: Towards participatory ethics. Children's Geographies 6(1):95-108.

Parr, H. 2007. Collaborative film-making as process, method and text in mental health research. Cultural Geographies 14(1):114-138.

http://dx.doi.org/10.1177/1474474007072822

Pearce, T., Smit, B., Duerden, F., Ford, J.D., Goose, A., and Kataoyak, F. 2010. Inuit vulnerability and adaptive capacity to climate change in Ulukhaktok, Northwest Territories, Canada. Polar Record 46(2):157-177. http://dx.doi.org/10.1017/S0032247409008602

Pearce, T., Ford, J.D., Duerden, F., Smit, B., Andrachuk, M., Berrang-Ford, L., and Smith, T. 2011. Advancing adaptation planning for climate change in the Inuvialuit Settlement Region (ISR): A review and critique. Regional Environmental Change 11:1-17.

http://dx.doi.org/10.1007/s10113-010-0126-4 
Pearce, T., Ford, J.D., Caron, A., and Kudlak, B.P. 2012. Climate change adaptation planning in remote, resource-dependent communities: An Arctic example. Regional Environmental Change 12(4):825-837. http://dx.doi.org/10.1007/s10113-012-0297-2

Petrasek MacDonald, J., Harper, S.L., Cunsolo Willox, A., Edge, V.L., and the Rigolet Inuit Community Government. 2013a. A necessary voice: Climate change and lived experiences of youth in Rigolet, Nunatsiavut, Canada. Global Environmental Change 23(1):360-371. http://dx.doi.org/10.1016/j.gloenvcha.2012.07.010

Petrasek MacDonald, J., Ford, J.D., Cunsolo Willox, A., and Ross, N.A. 2013b. A review of protective factors and causal mechanisms that enhance the mental health of Indigenous circumpolar youth. International Journal of Circumpolar Health 72: 21775.

http://dx.doi.org/10.3402/ijch.v72i0.21775

Piper, H., and Frankham, J. 2007. Seeing voices and hearing pictures: Image as discourse and the framing of imagebased research. Discourse: Studies in the Cultural Politics of Education 28(3):373-387. http://dx.doi.org/10.1080/01596300701458954

Prowse, T.D., Furgal, C., Bonsal, B.R., and Edwards, T.W.D. 2009. Climatic conditions in northern Canada: Past and future. Ambio 38(5):257-265. http://dx.doi.org/10.1579/0044-7447-38.5.257

Richmond, C.A.M. 2009. The social determinants of Inuit health: A focus on social support in the Canadian Arctic. International Journal of Circumpolar Health 68(5):471 - 487. http://dx.doi.org/10.3402/ijch.v68i5.17383

Schaefer, N. 2011. Using video in a participatory, multi-method project on young people's everyday lives in rural East Germany: A critical reflection. In: Heath, S., and Walker, C., eds. Innovations in researching youth. Basingstoke, United Kingdom: Palgrave Macmillan.

Schäfer, N., and Yarwood, R. 2009. Involving young people as researchers: Uncovering multiple power relations among youths. Children's Geographies 6(2):121-135. http://dx.doi.org/10.1080/14733280801963003

Smith, L. 2012. Decolonizing methodologies: Research and Indigenous peoples, 2nd ed. London and New York: Zed Books.
Statistics Canada. 2011a. National household survey: Table 4 Age distribution and median age for selected Aboriginal identity categories, Canada, 2011.

http://www12.statcan.gc.ca/nhs-enm/2011/as-sa/99011-x/2011001/tbl/tbl04-eng.cfm

Statistics Canada. 2011b. Census profile. http://www12.statcan.gc.ca/census-recensement/2011/dp-pd/ prof/index.cfm?Lang $=\mathrm{E}$

Stewart, S., Riecken, T., Scott, T., Tanaka, M., and Riecken, J. 2008. Expanding health literacy: Indigenous youth creating videos. Journal of Health Psychology 13(2):180 - 189. http://dx.doi.org/10.1177/1359105307086709

Suarez, P., Ching, F., Ziervogel, G., Lemaire, I., Turnquest, D., de Suarez, J.M., and Wisner, B. 2008. Video-mediated approaches for community-level climate adaptation. Institute of Development Studies (IDS) Bulletin 39(4):96-104.

Wenzel, G.W. 2009. Canadian Inuit subsistence and ecological instability - if the climate changes, must the Inuit? Polar Research 28(1):89-99. http://dx.doi.org/10.1111/j.1751-8369.2009.00098.x

Wexler, L. 2014. Looking across three generations of Alaska Natives to explore how culture fosters Indigenous resilience. Transcultural Psychiatry 51(1):73-92. http://dx.doi.org/10.1177/1363461513497417

Wexler, L., and Goodwin, B. 2006. Youth and adult community member beliefs about Inupiat youth suicide and its prevention. International journal of Circumpolar Health 65(5):448 - 458. http://dx.doi.org/10.3402/ijch.v65i5.18146

Wexler, L., Jernigan, K., Mazziotti, J., Baldwin, E., Griffin, M., Joule, L., Garoutte, J., Jr., and CIPA Team. 2013. Lived challenges and getting through them: Alaska Native youth narratives as a way to understand resilience. Health Promotion Practice 15(1):10-17. http://dx.doi.org/10.1177/1524839913475801

Wexler, L., Joule, L., Garoutte, J., Mazziotti, J., and Hopper, K. 2014. "Being responsible, respectful, trying to keep the tradition alive:" Cultural resilience and growing up in an Alaska Native community. Transcultural Psychiatry 51(5):693-712. http://dx.doi.org/10.1177/1363461513495085

White, A., and Bushin, N. 2011. More than methods: Learning from research with children seeking asylum in Ireland. Population, Space and Place 17(4):326-337. http://dx.doi.org/10.1002/psp.602 